\title{
Iron and Copper Containing Oxygen Reduction Catalysts from Templated Glucose-Histidine.
}

\begin{tabular}{|r|l|}
\hline Journal: & Fuel Cells \\
\hline Manuscript ID: & fuce.200900142.R1 \\
\hline Wiley - Manuscript type: & Original Research Paper \\
\hline Author: & 27-Oct-2009 \\
\hline Complete List of Authors: & $\begin{array}{l}\text { Galbiati, Ivano } \\
\text { Bianchi, Claudia } \\
\text { Longhi, Mariangela; Università degli Studi di Milano, Chimica Fisica } \\
\text { ed Elettrochimica } \\
\text { Formaro, Leonardo }\end{array}$ \\
\hline Keywords: & $\begin{array}{l}\text { Oxygen Reduction Reaction, Platinum-free Catalysts, C/N/Me } \\
\text { centers, Iron-Copper, Hard Templating }\end{array}$ \\
\hline
\end{tabular}

\section{scholarONE" \\ Manuscript Central}




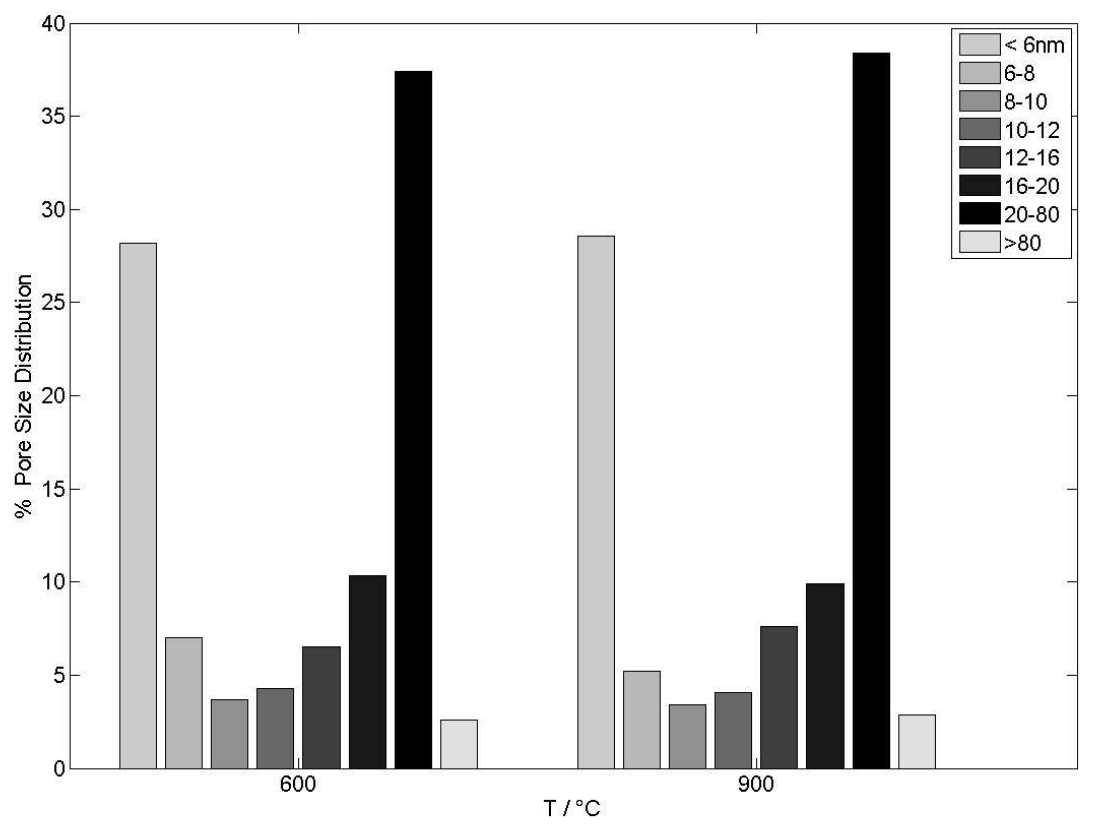

Pore Size Distributions at different temperatures. GluHistFe75. $338 \times 238 \mathrm{~mm}(96 \times 96 \mathrm{DPI})$ 


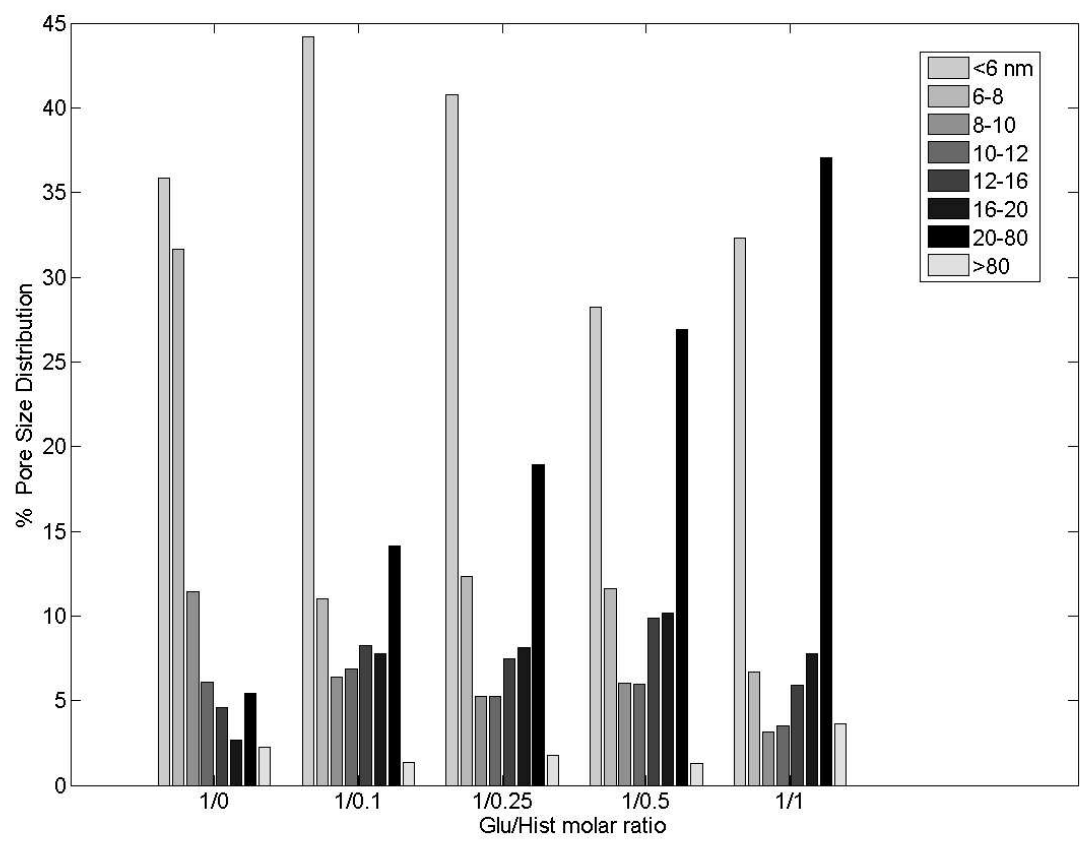

Pore Size Distributions at various Glu/Hist molar ratios $\left(T=600^{\circ} \mathrm{C}\right)$. $338 \times 243 \mathrm{~mm}(96 \times 96 \mathrm{DPI})$ 
Page 3 of 28

Fuel Cells

1
2
3
4
5
6
7
8
9
10
11
12
13
14
15
16
17
18
19
20
21
22
23
24
25
26
27
28
29
30
31
32
33
34
35
36
37
38
39
40
41
42
43
44
45
46
47
48
49
50
51
52
53
54
55
56
57
58
59
60

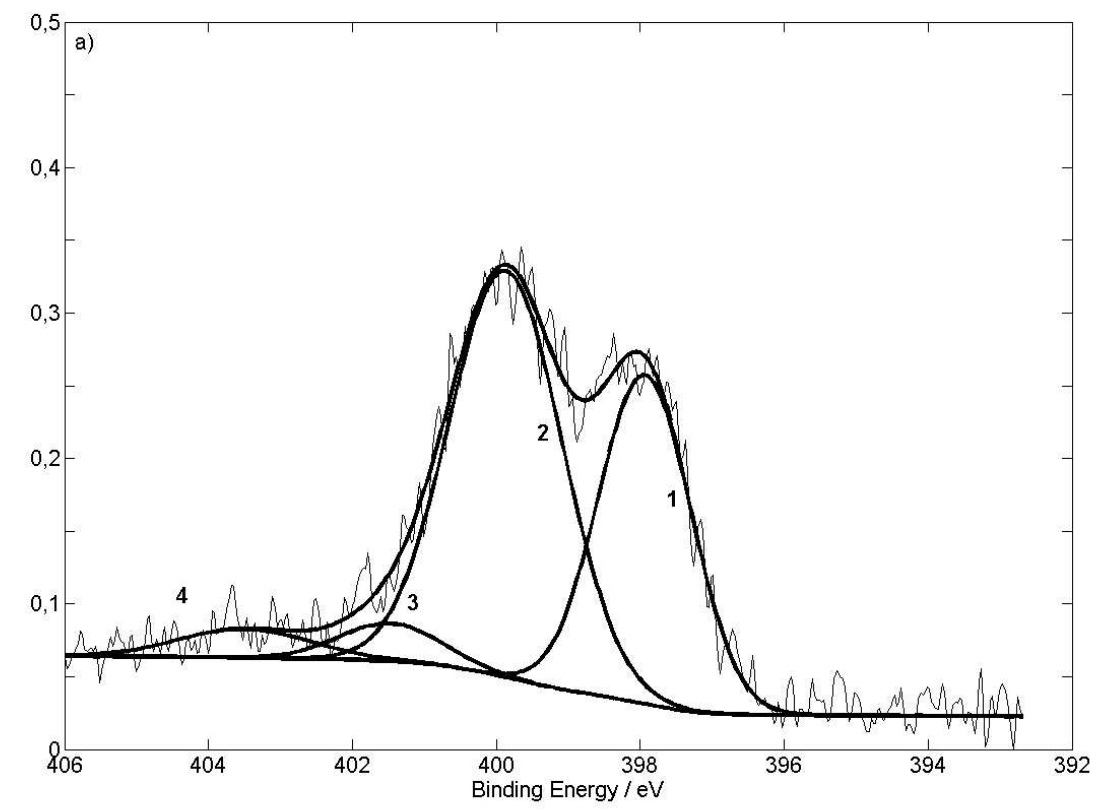

High resolution Nitrogen (1s) Spectra of GluHist: a) $T=600^{\circ} \mathrm{C} ; 1$ ) pyridinic N (N6) (B.E. $398-398.4$ $\mathrm{eV}$ ); 2) pyrrolic-N in five member ring and or pyridonic-N (N5) (B.E. 400-400.5 eV); 3) quaternary$\mathrm{N}$ (NQ), e.g. $\mathrm{N}$ in graphene structure (B.E. 401.5-402.2 eV); 4) pyridinic-N-oxide (NX) (B.E. 403.5$404.8 \mathrm{eV})$ B.E. are from [45-48]. $338 \times 232 \mathrm{~mm}(96 \times 96 \mathrm{DPI})$

Wiley-VCH 
High resolution Nitrogen (1s) Spectra of GluHist: b) $T=900^{\circ} \mathrm{C}$. 1) pyridinic N (N6) (B.E. $398-398.4$ $\mathrm{eV}$ ); 2) pyrrolic-N in five member ring and or pyridonic-N (N5) (B.E. 400-400.5 eV); 3) quaternary$\mathrm{N}$ (NQ), e.g. $\mathrm{N}$ in graphene structure (B.E. 401.5-402.2 eV); 4) pyridinic-N-oxide (NX) (B.E. 403.5$404.8 \mathrm{eV})$ B.E. are from [45-48]. $338 \times 232 \mathrm{~mm}(96 \times 96 \mathrm{DPI})$ 
Voltammograms in oxygen-saturated 0.1M HClO4. A) GluHist; B) GluHistFe0; C) GluHistFe25; D) GluHist75; E) GluHistFe100. ( $\mathrm{T}=25^{\circ} \mathrm{C}$; scan rate $5 \mathrm{mV} \mathrm{s}-1$; rotation rate $\left.700 \mathrm{rpm}\right)$. $338 \times 232 \mathrm{~mm}(96 \times 96 \mathrm{DPI})$ 


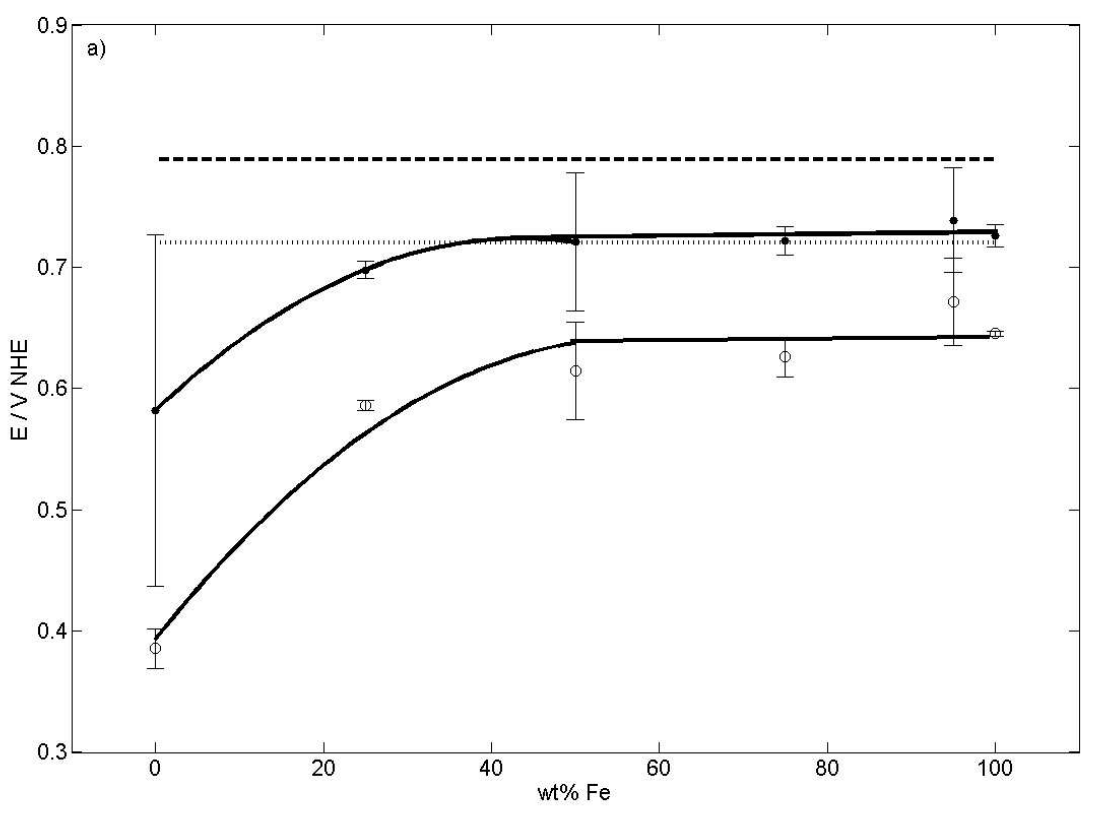

a) Incipient oxygen reduction potentials at different Fe wt \%: • and --- (heavy dashes) potentials at the intersection points in Fig. 5; $\circ$ and --- (light dashes) peak potentials of cathodic maxima at $\omega=0 \mathrm{rpm}$. Dashes are for EC-20 Pt catalyst, open and closed points are for home made carbons. $338 \times 232 \mathrm{~mm}(96 \times 96 \mathrm{DPI})$ 
b) Currents at $E=+0.420 \mathrm{~V}$ NHE at different wt $\% \mathrm{Fe}$.

Lines are a guide to the eye. Error bars represent standard deviation of experimental data. $(0.1 \mathrm{M}$ $\mathrm{HClO} 4$, scan rate $5 \mathrm{mV} \mathrm{s}-1$, rotation rate $700 \mathrm{rpm}, \mathrm{T}=25^{\circ} \mathrm{C}$.)

\section{$338 \times 232 \mathrm{~mm}(96 \times 96 \mathrm{DPI})$}




\title{
Iron and Copper Containing Oxygen Reduction Catalysts from Templated Glucose-Histidine.
}

\author{
Ivano Galbiati, Claudia L. Bianchi, Mariangela Longhi*, Andrea Carrà, Leonardo \\ Formaro
}

Dipartimento di Chimica Fisica ed Elettrochimica, Università degli Studi di Milano, Via Golgi 19, 20133 Milano Italy

[*] Corresponding author, Email:mariangela.longhi@unimi.it 


\begin{abstract}
Nitrogen doped carbons loaded with non-precious transition metals are currently investigated as substitutes of Pt-based catalysts for oxygen reduction in Polymer Electrolyte Fuel Cells (PEMFC's). This paper reports the preparation of one kind of such catalysts using glucose/histidine mixtures added with $\mathrm{Fe}$ and $\mathrm{Cu}$ salts in the presence of silica gels as hard templating agent to increase carbon surface area. The resulting carbons contain nitrogen in amounts that depend on heating temperature ( $\mathrm{T}=600$ and $\mathrm{T}=900^{\circ} \mathrm{C}$ ) on the glucose/histidine molar ratio and, more weakly, on the relative $\mathrm{Fe} / \mathrm{Cu}$ amount. Surface areas are a function of reactant concentration and heating temperature, whereas pore size and pore size distribution only depend on glucose-histidine molar ratio. Cyclic voltammetry results on oxygen reduction depend on $\mathrm{Fe} / \mathrm{Cu}$ ratio, the best result both in terms of incipient oxygen reduction potentials and currents being observed on samples only containing $\mathrm{Fe}$, with no $\mathrm{Cu}$ added.
\end{abstract}

Keywords: Oxygen Reduction Reaction, Platinum-free Catalysts, C/N/Me centers, Iron-Copper, Hard Templating, 


\section{Introduction}

Fuel cells, and more specifically PEMFC's, represent promising power systems to the world economy, with many applications and low environmental impact. A most important aspect concerning their widespread implementation is the cost of both polymeric membranes and catalytic electrode materials which are necessary to promote electrode reactions thus increasing fuel cell energy efficiency. This is especially true for the cathodic oxygen reaction (ORR), the best catalyst being at present based on the very expensive platinum metal or Pt-alloys (about 2250 \$/oz [1]). Therefore, a decrease in Pt amount (from 1.1 to $0.2 \mathrm{~g} / \mathrm{KW}$ in 2015 , DOE data [2]) or its replacement with nonprecious materials having comparable performance is necessary. Research on this subject started in the '60s [3] with a notable turning point from Yeager's work at the end of ' 80 s [4], and became a worldwide continuing issue with contributions from many authoritative research groups.

Among various materials, nitrogen modified carbons also containing non-precious transition metals (Fe and $\mathrm{Co}$ ) are considered interesting because of their ORR activity and reliability as confirmed by results from independent groups [5-15]. Several preparative methods are reported: 1) carbon impregnation with metal organosalts or cyanoderivatives, followed by thermal activation in the presence of e.g. ammonia gas [5]; 2) thermal treatment of nitrogen-containing metal complexes adsorbed onto carbon [16-36]; 3) polymerization of aromatic compounds, e.g. pyrrole [37,38], onto carbon surface followed by metal ion adsorption $\left(\mathrm{Co}^{2+}\right)$ to obtain porphyrine-like structures; 4$)$ thermal treatment of mixed precursors from a carbon and nitrogen source, respectively, e.g. glucose and an amino acid, added with transition metal salts ( $\mathrm{Fe}, \mathrm{Cu})[9,14]$. These latter materials are considered interesting because of the ease and flexibility of the 
synthetic route and, moreover, of the catalytic activity, with incipient oxygen reduction potentials closely approaching (by $\sim 40 \mathrm{mV}$ ) those of commercial Pt catalysts [14]. Unfortunately, however, they are reported with low stability [14]. Recently, thermodynamic criteria were put forward to model the catalytic activity of Ptfree bimetallic alloys [39] permitting to evaluate what metal, or combination of metals, may be most effective in ORR. As a result $\mathrm{Fe}^{2+} / \mathrm{Cu}^{+}$ions were shown most favourable. Interestingly these ions are also present in natural enzymatic systems like cytochrome $\mathrm{C}$ oxidase, an effective and selective catalyst in the reduction of oxygen to $\mathrm{H}_{2} \mathrm{O}$, based on a cooperative effect of the two ions.

Improving catalyst activity is not only a matter of varying composition but also involves morphological/textural aspects. By reference to carbon supported Pt catalysts, carbon origin, surface area, porosity and pore size distribution reportedly affect end material performances. Reviewing these aspects, Antolini [40] has recently shown that besides good electrical conductivity, carbon supports have to be characterized by high surface areas and high fractional pore percentage in the mesoporosity region $(2-50 \mathrm{~nm})$ in order to favour reactant mass transport to and from catalytic centers, the more so if the catalytic sites are preferentially located at inner positions of the carbon structure, in the micropore size region as reported by [41].

Histidine was chosen as the nitrogen-bearing precursor, because it contains both an imidazolic ring and a carboxyl group that, if retained in end products upon thermal activation, may presumably contribute to ORR activity [40-42]. In the attempt of increasing carbon surface area and at the same time controlling porosity in the mesoporosity range a hard template method was adopted using silica gel suspensions in 
water. Also, $\mathrm{Fe}^{2+}$ and $\mathrm{Cu}^{2+}$ in variable ratios were used to explore the entire composition range as suggested by the theoretical examination in [39].

\section{Experimental}

\subsection{Reagents}

Glucose, histidine, $\mathrm{Fe}(\mathrm{II})$ acetate, $\mathrm{Cu}$ (II) acetate, glacial acetic acid and Nafion (5 wt \% solution) were purchased from Aldrich and used as received. Silica (Silica Gel $60 \mathrm{HR}$ ) and $\mathrm{HClO}_{4}(60$ wt \%) were from Merck and Fluka, respectively. High purity water from a MilliQ system (Millipore) was used throughout. Nitrogen and oxygen (Sapio, 5nines) were used.

\subsection{Preparation of the catalytic materials}

A glucose (Glu in the following) solution in water $\left(1.68 \mathrm{~mol} \mathrm{dm}^{-3}\right)$ was added with histidine (Hist) in variable molar ratios: Glu/Hist=1/1 is indicated as GluHist in the following; Glu/Hist=2/1 as GluHist0.5; Glu/Hist=4/1 as GluHist0.25; Glu/Hist=10/1 as GluHist0.1. Adding equimolar glacial acetic was found necessary to dissolve histidine. $10 \mathrm{ml}$ of this solution were stirred with $4.3 \mathrm{~g}$ of silica for $5 \mathrm{~min}$ to form a gel, and stirred again 5 min after 15 min standing. The gel was loaded in a quartz reactor, degassed with $\mathrm{N}_{2}\left(100 \mathrm{~cm}^{3} \mathrm{~min}^{-1}\right)$ for about $5 \mathrm{~min}$ and inserted in a preheated vertical oven at $\mathrm{T}=600^{\circ} \mathrm{C}$ in order to carbonize as fast as possible the precursors, preserving the ordered room temperature gel structure in the final products. Heating was continued for $1 \mathrm{~h}$ under continuous $\mathrm{N}_{2}$ purging $\left(100 \mathrm{~cm}^{3} \mathrm{~min}^{-1}\right)$. Then the tube was rapidly quenched in air. Silica was removed in $3 \mathrm{M}$ boiling $\mathrm{NaOH}$ followed by repeated carbon washing/filtering (MilliQ water, $0.45 \mu \mathrm{m}$ Durapore filters) until water conductivity 
became lower than $4 \mu \mathrm{S}$. Products were dried in nitrogen $\left(100{ }^{\circ} \mathrm{C}, 24 \mathrm{~h}\right)$ and finally ground in an agate mortar. Metal containing catalysts were prepared by the same procedure but for the addition of acetate metal salts (Fe and $\mathrm{Cu}$ ions at $1 \mathrm{wt} \%$ total with respect to glucose+histidine, at variable ratios between them). The ratio of iron and copper salts was varied in a range from $0 \%$ to $100 \%$ iron: GluHistFe0: 0\% Fe/100 \% $\mathrm{Cu}$; GluHistFe25: 25\% Fe/75 \% Cu; GluHistFe50: 50\% Fe/50 \% Cu; GluHistFe75: 75\% Fe/25 \% Cu; GluHistFe95: 95\% Fe/5 \% Cu; GluHistFe100: 100\% Fe/0 \% Cu. All materials were heat-activated in a second step at $\mathrm{T}=900^{\circ} \mathrm{C}$ under constant $\mathrm{N}_{2}$ flow $\left(100 \mathrm{~cm}^{3} \mathrm{~min}^{-1}\right)$ in the following conditions: 30 min room temperature purging, ramping at $6^{\circ} \mathrm{C} \mathrm{min}{ }^{-1}$ and $3 \mathrm{~h}$ standing at $\mathrm{T}=900^{\circ} \mathrm{C}$, fast quenching to room temperature.

\subsection{Characterisation of materials}

$X$-ray Photoelectron Spectroscopy (XPS).

XPS measurements were performed with an M-Probe Instrument (SSI) equipped with a monochromatic $\mathrm{Al} \mathrm{K} \alpha$ source $(1486.6 \mathrm{eV})$ with a spot size of $200 \times 750 \mu \mathrm{m}$ and a pass energy of $25 \mathrm{eV}$, providing a resolution of $0.74 \mathrm{eV}$. The energy scale was calibrated with reference to the $4 \mathrm{f} 7 / 2$ level of a freshly evaporated gold sample $(84.00 \pm 0.1 \mathrm{eV})$ and to the $2 \mathrm{p} 3 / 2$ and $3 \mathrm{~s}$ levels of copper $(932.47 \pm 0.1$ and $122.39 \pm 0.15 \mathrm{eV}$, respectively). An electron flood gun was used to compensate for the buildup of positive charge on insulating samples: a value of $5 \mathrm{eV}$ was selected. For all samples, the $\mathrm{C} 1 \mathrm{~s}$ peak level was taken as the internal reference at $284.6 \mathrm{eV}$. Accuracy of reported binding energies (BEs) is approximately $\pm 0.2 \mathrm{eV}$. Quantitative data were carefully checked and reproduced several times. Uncertainty in spectral decomposition is estimated to be $\pm 1 \%$. Specific Surface Area. 
Surface area and porosity were determined by low temperature B.E.T. $\mathrm{N}_{2}$ adsorption using an SA3100 Coulter apparatus. Before measurement, samples were outgassed at $\mathrm{T}=80^{\circ} \mathrm{C}$ for $3 \mathrm{~h}$. Surface area and porosity were calculated from nitrogen isotherms using the instrumental software (Version 2.12).

TEM images were obtained by a Zeiss EFTEM LEO 912AB (120 kV) microscope

\subsection{Electrode and catalyst layer preparation}

Electrochemical characterisation was performed by the Thin Film Rotating Disk Electrode (TFRDE) method immobilizing small catalyst amounts onto the graphite tip (geometric surface area: $\mathrm{A}=0.0491 \mathrm{~cm}^{2}$ ) of a rotating disk electrode (EDI 101, Radiometer). Before use the tip was gently cleaned with soft sandpaper, polished by diamond powder (Aldrich) and finally degreased with ethanol. Catalyst aliquots (8 mg) were dispersed in water added with Nafion ( $1.5 \mathrm{ml}$ water, $4 \mu \mathrm{l} \mathrm{Nafion})$ and sonicated for $30 \mathrm{~min} ; 7 \mu \mathrm{l}$ of this mixture were pipetted onto the electrode tip and dried in a bottomup position above a tungsten lamp.

\subsection{Electrochemical measurements}

A two compartment cell with a graphite counterelectrode (Amel 201/S-016) and a $\mathrm{AgCl} / \mathrm{Ag}$ external reference electrode (Amel) in $3 \mathrm{M} \mathrm{NaCl}$ was used. The reference was connected to the cell by a salt bridge filled with the working electrolyte $\left(0.1 \mathrm{M} \mathrm{HClO}_{4}\right)$. Before each experimental run all glassware was washed by concentrated $\mathrm{H}_{2} \mathrm{SO}_{4}$ and rinsed in MilliQ water. The counterelectrode was cleaned with filter paper. The potentiostat was AMEL mod. 7050. Measurements were performed by an accurately reproducible procedure. Before $\mathrm{CV}$ recording, the electrode was conditioned cycling 45 
$\min$ in $\mathrm{N}_{2}$ in the potential range $\mathrm{E}=-0.275-+0.800 \mathrm{~V}$, followed by $100 \mathrm{~min}$ cycling in $\mathrm{O}_{2}$ saturated solution $(5 \mathrm{mV} / \mathrm{s}, \omega=1600 \mathrm{rpm})$. Then $\mathrm{O}_{2}$ reduction results were recorded in the same conditions at different electrode rotation rates. To verify electrode stability and internal reproducibility several CVs at $\omega=1600 \mathrm{rpm}$ were recorded in each run. After measurements in $\mathrm{O}_{2}$, CVs were again recorded in $\mathrm{N}_{2}$ to obtain background faradaic currents for $\mathrm{O}_{2}$ reduction data correction. Background charge values were also obtained by integration of $\mathrm{N}_{2}$ curves and used as a measure of real electrode surface area, normalizing the many investigated materials with respect to $\mathrm{Glu}\left(\mathrm{T}=900^{\circ} \mathrm{C}\right)$ that was assumed as an internal, arbitrary reference.

\section{Results and Discussion.}

In the presence of silica gel as a templating agent, carbon materials with expanded, sponge-like overall morphology are obtained as shown in Fig. 1 for a plain glucose sample heated at $\mathrm{T}=600{ }^{\circ} \mathrm{C}$. These effects are more quantitatively observed in the first two entry lines of Tab. 1 where the sample obtained in the presence of silica shows a tremendous increase of BET surface area $\left(1100 \mathrm{~m}^{2} / \mathrm{g}\right)$ instead of a few square meters $/ \mathrm{g}$ of the corresponding glucose-only sample. Though in the absence of comparison data without added silica, Tab. 1 shows that similarly high BET areas are obtained for all the samples. Interestingly, besides depending on silica, surface areas are a function of the used reactant, reactant concentration and heating temperature. Most relevant effects are due to histidine that, at even the lowest used molar ratio with respect to glucose (see GluHist0.1 in Tab. 1), causes a surface area decrease of $\sim 200 \mathrm{~m}^{2} / \mathrm{g}$, with a further decreasing trend taking place with increasing histidine/glucose molar ratio. Though moderate, opposite effects arise from metal ion addition, with surface areas in any case greater than the metal-free reference (sample GluHist) and also weakly increasing with 
increasing the $\mathrm{Fe}^{2+} / \mathrm{Cu}^{2+}$ ratio. As expected on general grounds, and in accordance with some matter loss visually observed as brownish gas emitted during the second heating at $\mathrm{T}=900^{\circ} \mathrm{C}$, surface areas decrease with increasing temperature. This decrease is in some relation with surface areas from the previous heating at $\mathrm{T}=600{ }^{\circ} \mathrm{C}$. As a fact, the last column in Tab. 1 shows that surface areas at $\mathrm{T}=900$ and $\mathrm{T}=600^{\circ} \mathrm{C}$ are in a ca. constant ratio of $0.75-0.9$. In a further aspect of this thermal behaviour, BET fractional pore volume distributions of many samples were found essentially independent of heating temperature. This is shown as an example in Fig. 2 for sample GluHistFe75. Then, the above surface area ratio and the lack of variation in pore volume distribution appear related, and jointly suggest that textural sample features are mostly established during the first heating in the presence of silica, followed by lesser rearrangements taking place at higher temperature after silica removal, these readjustments in their turn causing a moderate decrease of previous surface areas while leaving essentially unchanged porosity distribution.

Reactant composition effects on porosity are reported for the more extensively available results at $\mathrm{T}=600{ }^{\circ} \mathrm{C}$. In Fig. 3 histidine addition causes readjustments of the pristine glucose porosity, especially relevant at both the extremes of the accessible pore size range. In the low size region, pores $6-8 \mathrm{~nm}$ in size undergo a first redistribution in favour of the smaller ones $(6 \mathrm{~nm})$. Though with irregular variations, pores with these latter size are a large fractional value regardless of increasing histidine amounts. At the other extreme of size, increasing histidine causes the $20-80 \mathrm{~nm}$ pore size to become gradually more abundant, up to $\sim 35 \%$ of the overall sample porosity. Adding $\mathrm{Fe}^{2+}$ and $\mathrm{Cu}^{2+}$ ions in variable relative amounts has no apparent effect (not reported) on the porosity distribution of a number of carbons with constant Glu/Hist ratio 
$(\mathrm{Glu} / \mathrm{Hist}=1 / 1)$. Histidine is therefore most effective to promote pore size increase. This is at variance with Maruyama's results [9] on similar glucose/adenine carbons from a “dry" procedure without templates.

XPS survey results are shown in Tab. 2. Cu and Fe are undetected even for the lower used heating temperature. This situation is frequently observed, and unresolved, in the literature with the baffling outcome that, though undetected in outermost surface layers, added metals are indeed effective in promoting electrochemical ORR carbon behaviour. As also representative of the present results, we mention that Fe was undetected by both XPS and UPS [43] in spite of wide variation in added amounts, the maximum Fe value reaching $5.5 \mathrm{wt} \%$ with respect to the graphite oxide that was used in that case.

Moreover, in [44] it is reported that "after carbonization, the content of copper decreases as the copper ions are reduced into metallic copper nanoparticles. These nanoparticles are difficult to detect by XPS because they are coated by a thin carbon layer and migrate into the carbon matrix". As observed in Tab. 2 for samples heated at both $\mathrm{T}=600$ and $900{ }^{\circ} \mathrm{C}$, the relative abundance of $\mathrm{C} 1 \mathrm{~s}$ and $\mathrm{N} 1 \mathrm{~s}$ signals is moreover only weakly affected by metal addition.

Tab. 2 shows that N1s signals of GluHist $\left(\mathrm{T}=600{ }^{\circ} \mathrm{C}\right)$ are initially very high $(14 \%)$ and decrease with both increasing temperature $\left(7 \%, \mathrm{~T}=900^{\circ} \mathrm{C}\right)$ and decreasing the histidine amount adopted in preparation (4\%, Glu/Hist0.10). Notably, the temperature-dependent nitrogen decrease is accompanied by increasing C1s signals (from 82 to $91 \%$ ) showing that nitrogen removal also induces chemical carbon readjustments. Fig. 4 and Tab. 3 evidence that different nitrogen forms are present (Fig. 4a) with variable and temperature-dependent relative amounts (Fig. 4b). In GluHist for $\mathrm{T}=600{ }^{\circ} \mathrm{C}$ two main 
contributions are due to pyridinic (N6) and pyrrolic/pyridonic (N5) forms, in relative amounts of 36 and 55 atomic \%, respectively. Minor contributions are due to quaternary-N (NQ, 5\%), and pyridinic-N-oxide (NX, 4\%) (Relevant binding energies, B.E., are reported in the caption to Fig. 4 [45-48]). All these nitrogen forms undergo extensive redistribution upon heating to $\mathrm{T}=900{ }^{\circ} \mathrm{C}$, with $\mathrm{N} 6$ that decreases by $\sim 25 \%$, N5 by $\sim 75 \%$, such variations being counteracted by an extraordinary, tenfold increase of NQ, and doubling of NX. These readjustments are in accordance with literature data [48] by which N5 and N6 are thermally unstable with respect to NQ. This latter NQ represents a class of compounds in which substitutional nitrogen in graphene layers is theoretically advocated $[49,50]$ as active for ORR on metal-free catalysts.

However, results in Tab. 3 show that adding metals $(\mathrm{Fe}, \mathrm{Cu})$ to glucose-histidine precursors surprisingly does not cause a decrease in N5 and N6 signals with the increasing heating temperature, which would be expected from all the above literature data. This behaviour may be attributed to the formation of metal complexes from N5 and N6 groups, which indirectly corresponds to their thermal stabilization. In support of this hypothesis, it can be mentioned that in a recent paper [51] the signal at $399.3 \mathrm{eV}$, which is consistent with the present N5 and N6 species, was attributed to ironassociated pyridinic nitrogen species. This evidence can be considered as an indirect proof of the presence of metals onto the carbon surface, even though they are not directly determined by XPS.

Electrochemical results are collectively reported in Fig. 5 to permit comparison of the many materials obtained with variable relative $\mathrm{Fe} / \mathrm{Cu}$ weight amounts and a constant, equimolar Glu/Hist ratio. Results only concern $\mathrm{T}=900{ }^{\circ} \mathrm{C}$ given that weak or no activity 
was observed for $\mathrm{T}=600{ }^{\circ} \mathrm{C}$. All curves are net oxygen reduction currents, corrections for background residual currents and surface area normalization having been applied as described in the Experimental. Metal addition affects both incipient oxygen reduction potentials and currents. Notably enough, currents at first sharply increase by addition of $\mathrm{Cu}$ only (curve B) to the metal-free reference (curve A), and approach a limiting current behaviour at most negative potentials. Substituting a fractional $\mathrm{Fe}$ amount $(25 \%)$ for $\mathrm{Cu}$ (curve $\mathrm{C}$ ) causes the incipient oxygen reduction potential to shift anodic by $\sim 0.2 \mathrm{~V}$ at the expense however of a decrease in current that becomes comparable to those of the Glu/Hist blank. Thereafter, any increase in fractional Fe amount is accompanied by gradually increasing currents, better approaching a diffusion mass transport behaviour, with some, though limited, further increase in incipient reduction potentials. Figs. 6a, 6b are an overview outlining the observed metal dependence of oxygen reduction currents and incipient reduction potentials (at $\omega=700 \mathrm{rpm}$, constant) in comparison with similar values recorded on a commercial Pt catalyst (EC-20). In Fig. 6a two series of incipient potential data are used, a first set of values being rather qualitatively based on "kink" potentials at the cross-over point between a first, generally flat, and a second rising part of each I/E curve; the second set relying instead more quantitatively on the peak potential of a characteristic current maximum recorded at $\omega=0 \mathrm{rpm}$ [52] (such results are not reported for brevity). In Fig. 6a incipient potentials increase with increasing fractional $\mathrm{Fe}$ amount and reach well defined, limiting high values for $\mathrm{Fe} / \mathrm{Cu}$ greater than $\sim 50$ wt $\%$, lower than the corresponding Pt values by $\sim 40-50 \mathrm{mV}$. A similar increasing trend occurs for currents (Fig. 6b), without however any plateau and a maximum value at $100 \mathrm{wt} \% \mathrm{Fe}$. 
Then, we are left with open conclusions. On the one side, ORR behaviour improves with increasing $\mathrm{Fe} / \mathrm{Cu}$ ratio, reaching however a maximum in the presence of Fe only, in the absence of a second metal $(\mathrm{Cu})$, thus making uncertain that both metals are essential to catalytic ORR activity. Given the above XPS results, in both instances the question arises if Fe metal, possibly buried in the carbon matrix and/or complexed with nitrogen groups, is accessible, and to what extent, to the outside solution in order to form catalytically effective centres. Problems also arise concerning electrode durability given the limited amount of metal present as such or in ionic form.

\section{Acknowledgements}

Financial support from MIUR (Ministry of Instruction, University and Research) under Firb 2001 (contract RBAU01844A), FISR 2001 under the NUME Project "Sviluppo di membrane protoniche composite e di configurazioni elettrodiche innovative per celle a combustibile con elettrolita polimerico", and from Cariplo Foundation (Project 2008.2235) are gratefully acknowledged. Acknowledgments are due to Dr. Nadia Santo (C.I.M.A., Centro Interdipartimentale di Microscopia Avanzata, Università degli Studi di Milano) for careful TEM analyses.

\section{References}

[1] http://platinumprice.org/platinum-price-history.html

[2] http://www1.eere.energy.gov/hydrogenandfuelcells/mypp/pdfs/fuel_cells.pdf

[3] R. Jasinski, Nature 1964, 201, 1212.

[4] S. Gupta, D. Tryk, I. Bae, W. Aldred, E. Yeager, J. Appl. Electrochem. 1989, 19, 19.

[5] M. Lefèvre, E. Proietti, F. Jaouen, J.-P. Dodelet, Science 2009, 324, 71. 
[6] M. Yuasa, A. Yamaguchi, H. Itsuki, K. Tanaka, M. Yamamoto, K. Oyaizu, Chem. Mater. 2005, 17, 4278.

[7] N. P. Subramanian, S.P. Kumaraguru, H. Colon-Mercado, H. Kim, B. N. Popov, T. Black, D. A. Chen, J. Power Sources 2006, 157, 56.

[8] E. B. Easton, A. Bonakdarpour, R. Yang, D. A. Stevens, J. R. Dahn, J. Electrochem. Soc. 2008, 155, B547.

[9] J. Maruyama, I. Abe, Chem. Commun. 2007, 2007, 2879.

[10] T. E. Wood, Z. Tan, A. K. Schmoeckel, D. O'Neill, R. Atanasoski, J. Power Sources 2008, 178, 510.

[11] A. Garsuch, K. MacIntyre, X. Michaud, D. A. Stevens, J. R. Dahn, J. Electrochem. Soc. 2008, 155, B953.

[12] T. Schilling, M. Bron, Electrochim. Acta 2008, 53, 5379.

[13] A. H. C. Sirk, S. A. Campbell, V. I. Birss, J. Electrochem. Soc. 2008, 155, B592.

[14] J. Maruyama, N. Fukui, M. Kawaguchi, I. Abe, J. Power Sources 2008, 182, 489. [15] V. Nallathambi, J.-W. Lee, S. P. Kumaraguru, G. Wu, B. N. Popov, J. Power Sources 2008, 183, 34.

[16] O. Ikeda, H. Fukuda, H. Tamura, J. Chem. Soc., Faraday Trans. 1986, 82, 1561.

[17] R. Holze, I. Vogel, W. Vielstich, J. Electroanal. Chem., 1986, 210, 277.

[18] S. Dong and R. Jiang, Ber. Bunsenges. Phys. Chem. 1987, 91, 479.

[19] T. Sawaguchi, T. Itabashi, T. Matsue, I. Uchida, J. Electroanal. Chem. 1990, 279, 219.

[20] A. Widelöv, R. Lasson, Electrochim. Acta 1992, 37, 187.

[21] A. Widelöv, Electrochim. Acta 1993, 38, 2493. 
[22] B. Bittins-Cattaneo, S. Wasmus, B. Lopez-Mishima, V. Vielstiech, J. Appl. Electrochem. 1993, 23, 625.

[23] G. Faubert, G. Lalande, R. Côté, D. Guay, J.P. Dodelet, L.T. Weng, P. Bertrand, G. Dénès, Electrochim. Acta 1996, 41, 1689.

[24] G. Faubert, R. Côté, D. Guay, J.P. Dodelet, G. Dénès, P. Bertrand, Electrochim. Acta 1998, 43, 341.

[25] A.L. Bouwkamp-Wijnoltz, W. Visscher and J.A.R. van Veen, Electrochim. Acta 1998, $43,3141$.

[26] S.L. Gojković, S. Gupta, R.F. Savinell, J. Electroanal. Chem. 1999, 462, 63.

[27] R. Jiang, D. Chu, J. Electrochem. Soc. 2000, 147, 4605.

[28] M. Lefèvre, J.P. Dodelet, P. Bertrand, J. Phys. Chem. B 2000, 104, 11238.

[29] M. Lefèvre, J.P. Dodelet, P. Bertrand, J. Phys. Chem. B 2002, 106, 8705.

[30] A.L. Boukamp-Wijnoltz, W. Visscher, J.A.R. van Veen, E. Boellaard, A.M. van der Kraan, S.C. Tang, J. Phys. Chem. B 2002, 106, 12993.

[31] M. Lefèvre, J.P. Dodelet, Electrochim. Acta 2003, 48, 2749.

[32] H. Schulenburg, S. Stankov, V. Schu1nemann, J. Radnik, I. Dorbandt, S. Fiechter, P. Bogdanoff, H. Tributsch, J. Phys. Chem. B 2003, 107, 9034.

[33] J.A.R. van Veen, H.A. Colijn, J.F. van Baar, Electrochim. Acta 1988, 33, 801.

[34] G. Lalande, G. Faubert, R. Côté, D. Guay, J.P. Dodelet, L.T. Weng, P. Bertrand, J. Power Sources 1996, 61, 227.

[35] M. Bron, J. Radnik, M. Fieber-Erdmann, P. Bogdanoff, S. Fiechter, J. Electroanal. Chem. 2002, 535, 113.

[36] K. Sawai, N. Suzuki, J. Electrochem. Soc. 2004, 151, A2132.

[37] R. Bashyam, P. Zelenay, Nature 2006, 443, 63. 
[38] K. Lee, L. Zhang, H. Lui, R. Hui, Z. Shi, J. Zhang, Electrochim. Acta 2009, 54, 4704.

[39] Y. Ma, P. B. Balbuena, Chem. Phys. Lett. 2007, 440, 130.

[40] E. Antolini, Appl. Catal. B 2009, 88, 1.

[41] J. Herranz, M. Lefèvre, J.-P. Dodelet, J. Electrochem. Soc. 2009, 156, B593.

[42] C. W. B. Bezerra, L. Zhang, K. Lee, H. Liu, A. L. B. Marques, E. P. Marques, H. Wang, J. Zhang, Electrochim. Acta 2008, 53, 4937.

[43] P. Wang, Z. Wang, L. Jia, Z. Xiao Phys. Chem. Chem. Phys. 2009, 11, 2730.

[44] R. Fu, N. Yoshizawa, M. S. Dresselhaus, G. Dresselhaus, J. H. Satcher Jr., T. F. Baumann, Langmuir 2002, 18, 10100.

[45] D. Hulicova-Jurcakova, M. Seredych, G.Q. Lu, T. J. Bandosz Adv. Funct. Mater. 2009, 19, 438.

[46] S. Biniak, G. Szymański, J. Siedlewski, A. Światkowski, Carbon 1997, 35, 1799. [47] D. Long, J. Zhang, J. Yang, Z. Hu, G. Cheng, X. Liu, R. Zhang, L. Zhan, W. Qiao, L. Ling, Carbon 2008, 46, 1253.

[48] J. R. Pels, F. Kapteijn, J. A. Moulijn, Q. Zhu, K. M. Thomas, Carbon 1995, 33, 1641.

[49] R. A. Sidik, A. B. Anderson, N. P. Subramanian, S. P. Kamaraguru, B. N. Popov, J. Phys. Chem. B 2006, 110, 1787.

[50] N. P. Subramanian, X. Li, V. Nallathambi, S. P. Kumaraguru, H. Colon-Mercado, G. Wu, J.-W. Lee, B. N. Popov, J. Power Sources 2009, 188, 38.

[51] R. Kothandaraman, V. Nallathambi, K. Artyushkova, S. Calabrese Barton, Appl. Cat. B 2009, 92, 209. 
[52] F. Jaouen, S. Marcotte, J.-P. Dodelet, G. Lindbergh, J. Phys. Chem. B 2003, 107, 1376. 


\section{Figure Captions}

Figure 1. TEM image of Glu sample $\left(\mathrm{T}=600^{\circ} \mathrm{C}\right)$.

Figure 2. Pore Size Distributions at different temperatures. GluHistFe75.

Figure 3. Pore Size Distributions at various $\mathrm{Glu} / \mathrm{Hist}$ molar ratios $\left(\mathrm{T}=600^{\circ} \mathrm{C}\right)$.

Figure 4. High resolution Nitrogen (N1s) Spectra of GluHist: a) $\mathrm{T}=600^{\circ} \mathrm{C}$; b) $\mathrm{T}=900^{\circ} \mathrm{C}$. 1) pyridinic N (N6) (B.E. 398-398.4 eV); 2) pyrrolic-N in five member ring and/or pyridonic$\mathrm{N}(\mathrm{N} 5)$ (B.E. 400-400.5 eV); 3) quaternary-N (NQ), e.g. N in graphene structure (B.E. 401.5-402.2 eV); 4) pyridinic-N-oxide (NX) (B.E. 403.5-404.8 eV) B.E. are from [45-48]. Figure 5. Voltammograms in oxygen-saturated $0.1 \mathrm{M} \mathrm{HClO}_{4}$. A) GluHist; B) GluHistFe0; C) GluHistFe25; D) GluHist75; E) GluHistFe100. ( $\mathrm{T}=25^{\circ} \mathrm{C}$; scan rate $5 \mathrm{mV} \mathrm{s}^{-1}$; rotation rate $700 \mathrm{rpm})$.

Figure 6. a) Incipient oxygen reduction potentials at different Fe wt \%: • and --- (heavy dashes) potentials at the intersection points in Fig. 5; $\mathrm{O}$ and ... (light dashes) peak potentials of cathodic maxima at $\omega=0 \mathrm{rpm}$. Dashes are for EC-20 Pt catalyst, open and closed points are for home made carbons.

b) Currents at $\mathrm{E}=+0.420 \mathrm{~V} \mathrm{NHE}$ at different wt $\% \mathrm{Fe}$.

Lines are a guide to the eye. Error bars represent standard deviation of experimental data. $\left(0.1 \mathrm{M} \mathrm{HClO}_{4}\right.$; scan rate $5 \mathrm{mV} \mathrm{s}^{-1}$; rotation rate $700 \mathrm{rpm} ; \mathrm{T}=25^{\circ} \mathrm{C}$. $)$ 
Tables

Table 1. Specific Surface Area $\left(\mathrm{m}^{2} \mathrm{~g}^{-1}\right)$

\begin{tabular}{|c|c|c|c|c|c|}
\hline & $\begin{array}{c}\text { Glu/Hist } \\
\text { Molar Ratio }\end{array}$ & $\begin{array}{l}\mathrm{Fe} / \mathrm{Cu} \\
\mathrm{wt} \%\end{array}$ & $\begin{array}{c}\text { Surface } \\
\text { Area } \\
\left(\mathbf{m}^{2} \mathbf{g}^{-1}\right) \\
\left(\mathrm{T}=\mathbf{6 0 0}^{\circ} \mathrm{C}\right)\end{array}$ & $\begin{array}{c}\text { Surface } \\
\text { Area } \\
\left(\mathbf{m}^{2} \mathbf{g}^{-1}\right) \\
\left(\mathbf{T}=\mathbf{9 0 0}^{\circ} \mathbf{C}\right)\end{array}$ & $\mathbf{S}_{900} / \mathbf{S}_{600}$ \\
\hline Glu no silica & $1 / 0$ & - & 25 & - & - \\
\hline Glu & $1 / 0$ & - & 1143 & - & - \\
\hline GluHist0.1 & $1 / 0.10$ & - & 950 & 714 & 0.75 \\
\hline GluHist0.25 & $1 / 0.25$ & - & 728 & 700 & 0.96 \\
\hline GluHist0.50 & $1 / 0.50$ & - & 813 & - & - \\
\hline GluHist & $1 / 1$ & - & 603 & 541 & 0.90 \\
\hline GluHistFe0 & $1 / 1$ & $0 / 100$ & 670 & 564 & 0.84 \\
\hline GluHistFe25 & $1 / 1$ & $25 / 75$ & - & 555 & - \\
\hline GluHistFe50 & $1 / 1$ & $50 / 50$ & 696 & 559 & 0.80 \\
\hline GluHistFe75 & $1 / 1$ & $75 / 25$ & 665 & 589 & 0.88 \\
\hline GluHistFe100 & $1 / 1$ & $100 / 0$ & 698 & 587 & 0.84 \\
\hline
\end{tabular}

Table 2. Atomic C, O, N Percent Sample Compositions

\begin{tabular}{|c|c|c|c|c|c|c|}
\hline & \multicolumn{2}{|c|}{ N 1s\% } & \multicolumn{2}{|c|}{ O $1 \mathrm{~s} \%$} & \multicolumn{2}{|c|}{ C $1 \mathrm{~s} \%$} \\
\hline & $\mathrm{T}=600^{\circ} \mathrm{C}$ & $\mathbf{T}=900^{\circ} \mathrm{C}$ & $\mathbf{T}=600^{\circ} \mathrm{C}$ & $\mathbf{T}=900^{\circ} \mathrm{C}$ & $\mathbf{T}=600^{\circ} \mathrm{C}$ & $\mathrm{T}=900^{\circ} \mathrm{C}$ \\
\hline Glu & - & - & 6 & - & 94 & - \\
\hline GluHist & 14 & 7 & 4 & 2 & 82 & 91 \\
\hline GluHist0.10 & 4 & 4 & 5 & 2 & 91 & 94 \\
\hline GluHistFe0 & 14 & - & 4 & - & 82 & - \\
\hline GluHistFe50 & 13 & 7 & 5 & 2 & 82 & 91 \\
\hline GluHistFe75 & 13 & 8 & 5 & 2 & 83 & 90 \\
\hline
\end{tabular}


Table 3. Atomic N Percent Sample Compositions

\begin{tabular}{|c|c|c|c|c|c|c|c|c|}
\hline & \multirow[t]{2}{*}{ B.E. eV } & \multirow[t]{2}{*}{ Description } & \multicolumn{2}{|c|}{ GluHist } & \multicolumn{2}{|c|}{ GluHistFe50 } & \multicolumn{2}{|c|}{ GluHistFe75 } \\
\hline & & & $\mathrm{T}=600^{\circ} \mathrm{C}$ & $\mathrm{T}=900^{\circ} \mathrm{C}$ & $\mathrm{T}=600^{\circ} \mathrm{C}$ & $\mathbf{T}=900^{\circ} \mathrm{C}$ & $\mathrm{T}=600^{\circ} \mathrm{C}$ & $\mathrm{T}=900^{\circ} \mathrm{C}$ \\
\hline N6* & 398.0-398.4 & pyridinic $\mathrm{N}$ & 36 & 27 & 39 & 37 & 38 & 36 \\
\hline N5* & $400.0-400.5$ & $\begin{array}{l}\text { pyrrolic-N in five member } \\
\text { ring and or pyridonic-N }\end{array}$ & 55 & 14 & 48 & 48 & 51 & 45 \\
\hline $\mathrm{NQ}^{*}$ & $401.5-402.2$ & quaternary-N & 5 & 52 & 4 & 5 & 8 & 16 \\
\hline $\mathrm{NX}^{*}$ & $403.5-404.8$ & pyridinic-N-oxide & 4 & 7 & 9 & 10 & 3 & 3 \\
\hline
\end{tabular}

* Specification in the text 


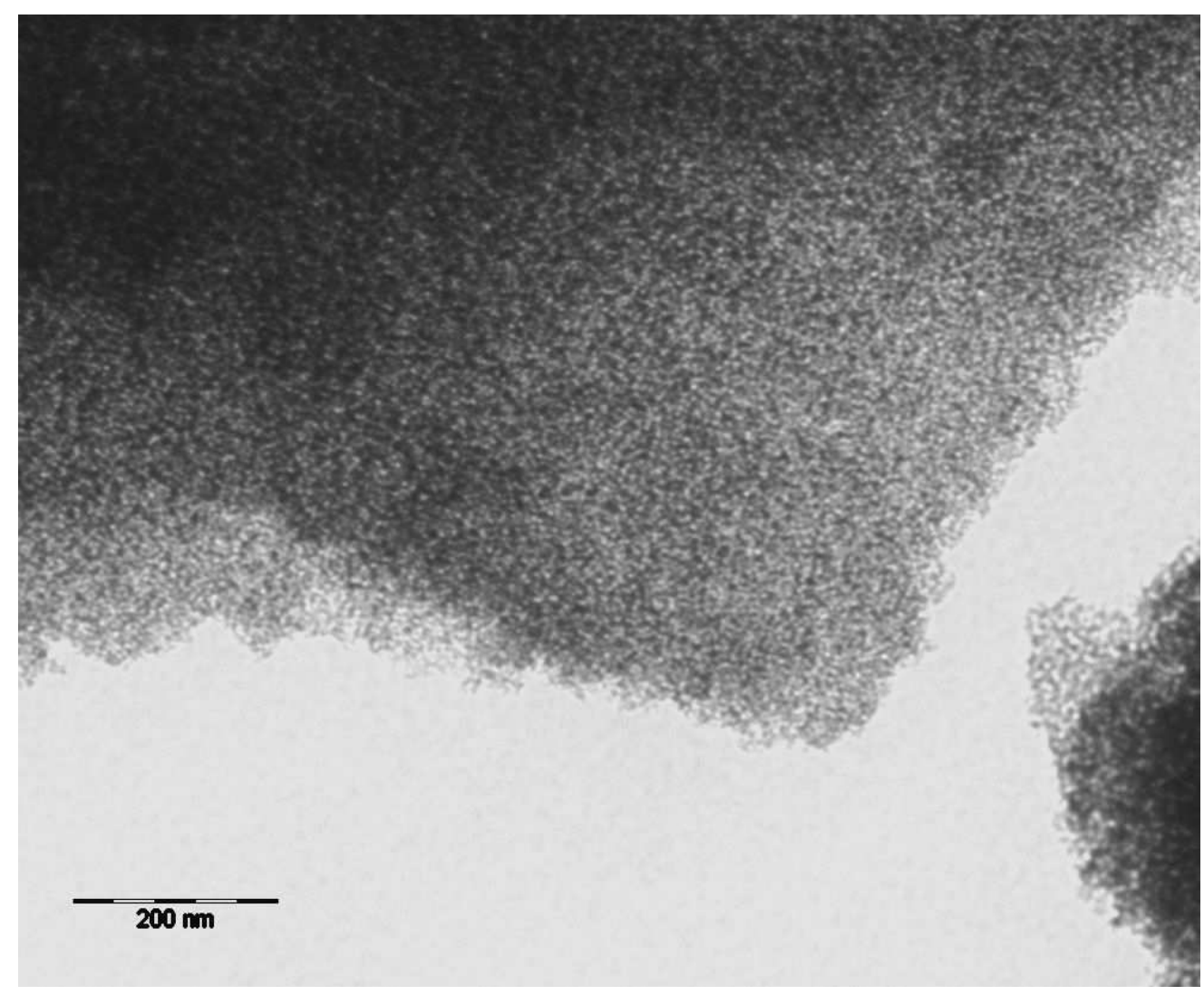

TEM image of Glu sample $\left(T=600^{\circ} \mathrm{C}\right)$. $349 \times 288 \mathrm{~mm}$ (72 $\times 72$ DPI) 